\title{
Familia - temelie a virtuţilor şi a legăturii indisolubile dintre soţi
}

\begin{abstract}
The family - the foundation of virtues and indissoluble bond between spouses. One of the many quotable passages from the writings of Saint John Chrysostom is located in his twentieth homily on Ephesians. It reads: "If we regulate our households [properly]..., we will also be fit to oversee the Church, for indeed the household is a little Church. Therefore, it is possible for us to surpass all others in virtue by becoming good husbands and wives"1. Most often, this passage has been invoked as proof text supporting high sacramental interpretations of marriage. The aim of the present study is to demonstrate how the family, created by God, is, at the same time, the permanent source of Christian virtues and indissoluble bond between spouses. Living in obedience to God and fulfilling His will, the Christian family is the state of Christianity.
\end{abstract}

Keywords: the traditional Christian family, visions of the Family, state, the contemporary secular culture.

\footnotetext{
*PhD Candidate, Faculty of Orthodox Theology at "1 Decembrie 1918" University in Alba Iulia, Romania.
} 


\section{Alin-Vasile GOGA}

\section{Introducere}

Intre Biserică şi familie, de multe ori, şi pe bună dreptate, s-au făcut asemănări de tipul: familia este Biserica mică şi Biserica este familia mare. O Biserică din care lipseşte familiaritatea ar putea fi o asociaţie, dar niciodată Biserică ${ }^{2}$ Tocmai spiritul familiarităţii este ceea ce exprimă, în modul cel mai pregnant, faptul că membrii Bisericii au o viaţă comunitară, aspect esenţial pentru comunitatea ai căror membri sunt efectiv, şi că aceştia sunt mădulare ale Trupului mistic al lui Hristos şi, totodată, ,un duh cu El” (I Cor. 6, 17)3.

Făcând o paralelă între problema teologică abordată în materialul de faţă şi sistemul medical, putem conchide asupra faptului că raportul dintre virtuţi şi viaţa de familie se constituie asemenea ciclului cardiac, format din sistolă şi diastolă. Sistola presupune contracţia miocardului, pe când diastola se referă la perioada de relaxare a acestuia, la dilataţie. Iisus Hristos a asumat în jertfa Crucii întreaga creaţie. Pe de altă parte, familia este asumată în Taina Întrupării Fiului lui Dumnezeu. $\mathrm{Cu}$ alte cuvinte, familia se contractă şi se încarcă ,de Hristos”, asistând la un fenomenul pe care 1-aş putea denumi sistola ecclesiei. Fiind nevoie de dilataţie, ea „pompează” în lume ,viaţa sa în Hristos şi cu Hristos, condusă de către Duhul Sfânt”, conform spuselor teologului rus Serghei Bulgakov. Această acţiune de ,pompare” a valorilor morale hristice din sânul familiei se poate numi diastola ecclesiei.

\section{Comuniunea indisolubilă dintre Biserică şi Familie - geneza relaţiilor interpersonale}

În cele ce urmează, asistăm la o comuniune indisolubilă între Biserică şi Familie, o comuniune de ajutor reciproc. Harul Mântuitorului Iisus Hristos îi face capabili pe soţi să se iubească întocmai cum Hristos

${ }^{2}$ Gloria H. Albrecht, Ideals and Injuries: The Denial of Difference in the Construction of Christian Family Ideals, in Journal of the Society of Christian Ethics, 25, 1(2005), Washington (USA), Georgetown University Press, p. 170.

${ }^{3}$ Pr. Vasile Răducă, Familia creştină şi riscul secularizării, în „Lumina de duminică”, 6 februarie 2011, p. 8-9. 
a iubit Biserica Sa şi, implicit, pe noi. Prin har şi prin credinţă, dragostea conjugală devine dăruire conjugală. Soţii se aduc pe sine jertfă pe „crucea familiei”, fiind chemaţi la o convieţuire impecabilă, sinceră şi pentru întreg restul vieţii. Darul fiecărui soţ către celălalt, implicat în schimbul reciproc de daruri faţă de soţia sa, este iubirea conjugală. Această iubire îi implică pe cei doi într-o cunoaştere reciprocă, astfel încât ei devin ,un singur trup” (Fac. 2, 24); devin colaboratorii Logosului în vederea dăruirii de viaţă unei alte persoane umane, ca rod al dragostei şi al unităţii lor conjugale, sinteză vie şi indisolubilă de fiinţa celor doi, în calitate de tată şi mamă.

Familia nu este doar biologie materială, ci şi biologie spirituală. Vorbind despre acest tip de unitate specifică familiei, Sfântul Ioan Hrisostom spune: „Când soţul şi soţia se unesc în căsătorie, ei nu formează imaginea a ceva pământesc, ci a lui Dumnezeu însuşi"4. Unitate în multiplu a dogmei trinitare se arată în adevărul vieţii conjugale, va spune Paul Evdokimov. „Acolo unde sunt doi, Eu voi fi în mijlocul lor." Clement Alexandrinul aplică aceste cuvinte căsătoriei. Iar Sfântul Ioan Hrisostom spune: „Cel care nu este căsătorit nu deţine în el însuşi totalitatea fiinţei, ci numai jumătatea sa" şi în altă parte va spune: „Bărbatul şi femeia nu sunt una, ci o singură fiinţă”.

\section{Familia - mediul în care se revarsă darurile Duhului Sfânt}

Darurile nenumărate şi diverse ale Duhului Sfânt sunt înflorirea harului divin în suflet, împroprierea şi personalizarea lui. Darurile Duhului sunt, prin urmare, roadele colaborării concrete a omului cu harul divin, talanţii înmulţiţi în arşiţa şi sudoarea zilei. Aceste daruri sunt primite prin Taina Mirungerii, Taina pecetluirii cu Duhul Sfânt. Urmând profetului Isaia $(11,2-3)$, Biserica vorbeşte despre şapte daruri ale Duhului. Luându-le din Domnul Hristos („din al Meu va

\footnotetext{
${ }^{4}$ Sfântul Ioan Hrisostom, P.G. 62, p. 387.

${ }^{5}$ Paul Evdokimov, Ortodoxia, Traducere de Dr. Irineu Ioan Popa, Bucureşti, EIBMBOR, 1996, p. 320.
} 


\section{Alin-Vasile GOGA}

lua”), Duhul le sădeşte în suflete: „Şi Se va odihni peste El Duhul lui Dumnezeu, duhul înţelepciunii şi al înţelegerii, duhul sfatului şi al tăriei, duhul cunoştinţei şi al bunei-credinţe. Şi-L va umple pe El duhul temerii de Dumnezeu". După Sfântul Maxim Mărturisitorul, prin darul temerii încetăm să mai păcătuim, iar prin cel al tăriei începem lucrarea virtuţilor. Celelalte daruri ne conduc spre iluminare.

Roadele Duhului însă, care sunt daruri sporite haric prin lucrarea de sfinţire a omului, sunt enumerate de către Sfântul Apostol Pavel: „Iar roada Duhului este dragostea, bucuria, pacea, îndelungărăbdarea, bunătatea, facerea de bine, credinţa, blândeţea, înfrânarea, curăţia" (Gal. 5, 22).

Darurile cu totul speciale pe care Dumnezeu le-a dat unor creştini, mai ales la începutul Bisericii pentru naşterea, răspândirea şi consolidarea ei, sunt numite harisme (facerea de minuni, proorocia, apostolia etc. - cf. I Cor. 12, 8-10). Lucrând prin minuni ce izbeau ochiul şi zguduiau sufletul, harismaticii aveau rolul, aproape constrângător, de a aduce pe cei ce nu credeau la credinţă. Unele dintre aceste harisme (glosolalia sau vorbirea în limbi, tâlcuirea limbilor) au încetat pentru că şi-au atins scopul pentru care au fost date.

În sufletele curate şi sfinte nu găzduiesc doar darurile cereşti, ci Dăruitorul Însuşi, Preasfânta Treime. Dumnezeu ne cere inimile noastre spre a locui El Însuşi în ele. Cum El nu vrea din ale noastre, ci pe noi, nu ne dăruieşte din ale Sale, ci ni se dăruieşte El Însuşi, ca „Cel Ce Se împarte şi nu Se desparte, Cel Ce Se mănâncă pururi şi niciodată nu Se sfârşeşte şi pe cei ce se împărtăşesc îi sfinţeşte" .

Sub acest aspect, familia creştină este precedată de Biserică. Ea se constituie ca mare taină în Hristos şi în Biserică (cf. Efes. 5, 32). Credinţa în Hristos, iubirea pentru El şi fidelitatea faţă de învăţătura Sa fac din oameni mădulare ale Trupului mistic al lui Hristos. În baza iubirii, a încrederii şi a curăţiei prin care cei doi s-au pregătit pentru

\footnotetext{
${ }^{6} \mathrm{http}: / /$ ziarullumina.ro/darurile-duhului-sfant-82548.html, accesat în data de 1 martie 2015, ora. 02.35 .
} 
căsătorie, în baza fidelităţii unuia faţă de altul, soţii primesc harul lui Dumnezeu ca să devină un alt fel de unitate funcţională în interiorul Trupului mistic al lui Hristos.

Dacă cei care vor să-şi constituie o familie în Biserică vor avea conştiinţa că sunt organe vii în marele organism al Bisericii, după ce îşi vor fi constituit familia, vor percepe că aceasta este un alt tip de unitate funcţională în acelaşi Trup divin al lui Hristos. Dacă în interiorul familiei soţii se vor privi unul pe altul cu ochii cu care Hristos priveşte mădularele Trupului Său, familia va fi, cu adevărat, locul, spaţiul şi instituţia de bază în care se vor pune în lucrare virtuţile cereşti: înţelepciunea, înţelegerea cea mai potrivită dintre soţi, buna sfătuire, puterea de a rezista ispitelor pe care nu le-ar putea birui de unii singuri, cumpătarea, bunătatea şi altele asemenea lor. În acest fel se va asigura împlinirea celor trei condiţii în vederea bunei funcţionări a familiei: monogamia, fidelitatea şi indisolubilitatea ${ }^{7}$.

Eficacitatea, providenţialitatea şi utilitatea Bisericii într-o familie, comunitate, naţiune depinde, în mare parte, de importanţa şi rolul pe care i le alocă familiei, şi cum administrează şi iconomiseşte problemele actuale ale familiei, ale societăţii şi, implicit, ale sale.

\section{Virtuţile creştine, mlădițe din trupul hristic al familiei creştine}

În ceea ce priveşte virtuţile creştine, putem afirma faptul că:

„virtutea este un efort de a zugrăvi chipul dumnezeiesc în comportarea şi viaţa noastră. Provenind din latinescul vir care înseamnă bărbat, om, bărbăţie, tărie, virtutea poartă în sine subînţelesul puterii omeneşti. Virtutea este orientarea obişnuită şi fermă a voinţei şi a întregului caracter de a acţiona în feluri specifice şi concrete, adecvate celor aflaţi în procesul creşterii în chipul lui Hristos şi theosis"8.

„Ţinta virtuților este eliberarea de patimi sau nepătimirea"".

\footnotetext{
${ }^{7}$ Pr. Vasile Răducă, art. cit., p. 9.

${ }^{8}$ PS Irineu Pop-Bistriţeanul, Chipul lui Hristos în viaţa morală a creştinului, Cluj-Napoca, Editura Renaşterea, 2001, p. 252.

${ }^{9}$ Cap. de char. II, 16; P.G. 90, 988 D; Quest ad Thalas, q. 55; P.G. 91, 541 B;
} 
Poruncile şi virtuţile sunt „leacuri curăţitoare ale stării noastre pătimaşe" ${ }^{\prime}$. Dacă patimile sunt boli ale sufletului, ce atentează la viaţa omului, şubrezindu-i trupul şi omorându-i sufletul, boli ce se încuibează în inima omului oarecum din afară şi datorită lipsei lui de trezvie, virtuţile sunt starea firească de sănătate a sufletului. În timp ce patimile sunt nişte ,accidente” şi adaosuri reproşabile firii omeneşti, virtutea se află în suflet, în chip firesc. Prin păcat şi patimi, omul dobândeşte o deprindere străină şi contrară firii, se află în stare de boală şi robie sufletească. Prin virtute, însă, ,primim deprinderea noastră proprie, sau ne reîntoarcem la sănătatea noastră, ca de la o orbire oarecare, la lumina proprie, sau ca de la o boală oarecare, la sănătatea noastră după fire" ${ }^{11}$. Lipsa virtuţilor este, din acest motiv, „maica morţii”" ${ }^{2}$, pe când prezenţa lor naşte nemurirea ${ }^{13}$. Fiecare patimă are o virtute contrară, pe care omul trebuie să o descopere

Cap. de char. II, 34; P.G. 90, 996 B; Cap. duc. I, 32; P.G. 90, 1096 A, apud. PS Irineu Pop-Bistriţeanul, op. cit., p. 253.

${ }^{10}$ Sfântul Isaac Sirul, Cuvinte despre sfintele nevoinţe, în Filocalia sfintelor nevointe ale desăvârşirii, volumul X, Traducere, introducere şi note de Pr. Prof. Dr. Dumitru Stăniloae, Bucureşti, Editura Institutului Biblic şi de Misiune al Bisericii Ortodoxe, 1981, p. 477: „De aceea ne-a dat nouă poruncile Lui de viată făcătoare, ca pe nişte leacuri curăţitoare ale stării noastre pătimaşe. Căci ceea ce sunt leacurile pentru trupul bolnav, aceea sunt poruncile pentru sufletul pătimaş. Şi e vădit că poruncile s-au dat împotriva patimilor, spre tămăduirea sufletului care a căzut.”

${ }^{11}$ Ava Dorotei, Ale celui între sfinţi, părintele nostru Dorotei. Felurite învăţ̆ături lăsate ucenicilor săi când a părăsit mănăstirea Avei Serid şi a întemeiat cu ajutorul lui Dumnezeu mănăstirea sa, după moartea Avei Ioan, proorocul, şi după tăcerea desăvârşită a Avei Varsanufie, în Filocalia sfintelor nevoințe ale desăvârşirii, volumul IX, Traducere, introducere şi note de Pr. Prof. Dr. Dumitru Stăniloae, Bucureşti, Editura Institutului Biblic şi de Misiune al Bisericii Ortodoxe, 1981, p. 594-595.

${ }^{12}$ Talasie Libianul, Despre dragoste, înfrânare şi petrecerea cea după minte, în Filocalia sfintelor nevoinţe ale desăvârşirii, volumul IV, Traducere, introducere şi note de Pr. Prof. Dr. Dumitru Stăniloae, Bucureşti, Editura Institutului Biblic şi de Misiune al Bisericii Ortodoxe, 1981, p. 18.

${ }^{13}$ Ibidem. 
şi să o lucreze până la desăvârşire. Înaintarea în lucrarea acesteia înseamnă, în acelaşi timp, distrugerea patimii contrare. Lupta împotriva patimilor, pentru dobândirea şi practicarea virtuţilor, aduce în sufletul celui duhovnicesc adevărata fericire, întrucât „virtutea este cu mult mai vrednică de cinste decât bogăţia" ${ }^{14}$.

Virtuţile sunt în număr de şapte, iar Sfântul Maxim Mărturisitorul le prezintă în următoarea ordine: credinţa, frica, înfrânarea, răbdarea, speranţa, nepătimirea, iubirea. Toate acestea însă sunt în strânsă legătură cu postul, paza minţii, rugăciunea, citirea pioasă, răbdarea necazurilor, pocăinţa şi lacrimile, atitudinea blândă şi duhul umilit. Începutul tuturor virtuţilor îl constituie credinţa, iar, la sfârşit, se află iubirea ${ }^{15}$.

\section{Raportul dintre virtuţile omului singur şi virtuţile dobândite în familie}

În sânul familiei, fără să se facă abstracţie de vreuna din calităţile şi funcţiile firii umane ale soţilor, aceştia dobândesc capacitatea de a-şi depăşi natura lor proprie prin împroprierea unor virtuţi pe care le pot dobândi doar în mod colectiv, nicidecum singuri şi lipsiţi de harul lui Dumnezeu ${ }^{16}$. În starea sa naturală (mai degrabă denaturată prin păcatul protopărintesc), omul nu este altruist şi nici generos, nici smerit, întrucât el doreşte să domine, fie că se află în individualismul său intim, fie că se află în societate. Acest spirit de dominare a celuilalt manifestat prin nesinceritate atrage după sine o cultivare a infidelităţii şi a aventurilor sentimental-erotice. Solidaritatea cultivată în diferite forme extraeclesiale nu e decât dovada manifestată într-un mod deghizat a instinctului conservării speciei.

\footnotetext{
${ }^{14}$ Nil Ascetul, Cuvânt ascetic, în Filocalia sfintelor nevoinţe ale desăvârşirii, volumul I, Traducere, introducere şi note de Pr. Prof. Dr. Dumitru Stăniloae, Bucureşti, Editura Institutului Biblic şi de Misiune al Bisericii Ortodoxe, 1981, p. 217.

${ }^{15}$ Cap. de char. 1, 1-2; P.G. 90, 961 AB, apud. PS Irineu Pop-Bistriţeanul, op. cit., p. 254.

${ }^{16}$ Isaac Jesuvi Julius, Globalization and Christian ministry to the family, in Ogbomoso Journal of Theology, 10 Dec. 2005, Nigeria, p. 156.
} 


\section{Alin-Vasile GOGA}

Familia, care a primit harul lucrător al Sfântului Duh ca urmare a mijlocirii Bisericii, se alcătuieşte din membri care au renunţat întru totul la egoism; altruismul atrage după sine conştiinţa însemnătăţii unui soţ pentru celălalt în întreaga iconomie a lui Dumnezeu. În această familie se vor naşte virtuţile: iubirea sinceră, totală şi jertfelnică, îngăduinţa, fidelitatea, înţelegerea celuilalt, ascultarea, participarea neegoistă la fericirea celuilalt, smerenia, rugăciunea continuă şi în comun etc., sub forma unor daruri venite de Sus. Toate aceste virtuţi, dobândite colectiv, constituie tot atâtea moduri de depăşire a condiţiei naturale ale omului. În cadrul familiei, omul este parte constituantă a unui sistem de relaţii pe care nu le poate cunoaşte decât cel care îşi întemeiază familia. Supuse unei atente analize, virtuţile, care se reîntâlnesc în familia binecuvântată de către Dumnezeu şi care fructifică această binecuvântare, sunt aceleaşi cu virtuţile membrilor conştient-activi ai Trupului hristic. Din acest motiv, Sfântul Ioan Gură de Aur a denumit familia, pe bună dreptate, ,,biserica din casă" ${ }^{17}$. În familie sunt cultivate o serie de virtuţi care sunt întâlnite doar de către cei care au ales să îşi trăiască viaţa în altruismul familial.

Atât familia, cât şi Biserica au un rol esenţial în perpetuarea şi menţinerea vie a credinţei. Viaţa aduce cu ea multe valuri şi curente, unii se lasă în voia acestora, alţii însă aleg să le înfrunte. De-a lungul istoriei, Biserica a reprezentat „o stâncă a ordinii”"18 în lumea aceasta aflată într-o permanentă schimbare şi trecere. În faţa acestor realităţi, Biserica poate fi soluţia, iar aceasta nu poate fi alta decât cea a Mântuitorului, pentru că „Iisus Hristos, ieri şi azi şi în veci, este acelaşi” (Evr. 13,8). Soluţia propusă de către Fiul lui Dumnezeu este familia monogamă, creştină, fondată pe unirea dintre un singur bărbat şi o femeie, unire care nu se numeşte nici individualism, dar nici colectivism, ci comuniune în iubire. Ea este cadrul în care se

\footnotetext{
${ }^{17}$ Pr. Gleb Kaleda, Biserica din casă, trad. din limba rusă de Lucia Ciornea, Bucureşti, Editura Sophia, 2008, p. 7.

${ }^{18}$ Sfântul Ioan Gură de Aur, op. cit., p. 53.
} 
formează generaţiile viitoare de oameni, este locul în care se formează personalitatea şi care alcătuieşte firescul legăturii dintre soţi.

Familia este templul sfânt, o vistierie a plinătăţii virtuţilor creştine. Ea este, în egală măsură, o celulă din care s-a născut şi pe care se fondează societatea oamenilor, dar şi o comunitate eclezială, mărturisitoare a Împărăţiei lui Dumnezeu. $O$ viaţă creştină presupune ca membrii familiei creştine să facă cel puţin patru lucruri împreună: să se roage acasă, să stea la masă, să participe duminica la Sfânta Liturghie şi să petreacă timpul cu folos, în cadrul unei destinderi agreabile. Acest lucru presupune ca membrii familiei, înainte de a fi soț şi soţie, fiu şi fiică, să fie buni prieteni ${ }^{19}$. Sfầntul Ioan Gură de Aur, neîntrecut rapsod al familiei creştine, considera că Dumnezeu ne-a creat în aşa fel încât să avem nevoie unii de alţii, să nu putem trăi fericiţi decât în comuniune de simţire şi trăire şi de aici şi înalta exprimare a Sfântului Părinte, care socotea că „,mai bine ne-ar fi de a trăi în întuneric decât de a fi fără prieteni” ${ }^{20}$.

În lumina credinţei creştine, soţii îşi sunt unul altuia dar şi binecuvântare. Astfel, pentru un soț dreptmăritor, soţia sa reprezintă cea mai frumoasă binecuvântare pe care Dumnezeu-Iubire i-o poate oferi bărbatului, pentru ca aceasta să îi împodobească viaţa şi sufletul cu trăsăturile legate de „eternul” ei feminin: căldura sufletească, bunătatea, delicateţea, sensibilitatea, fiind sprijin şi ajutor pe valurile atât de învolburate ale vieţii prezente, către ţărmul mântuirii. Sau,

${ }^{19}$ Lisa Sowle Cahill, A Christian Social Perspective on the Family, in The Mennoite Quarterely Reviews, 75, Nr. 2, April, the Goshen College (USA), 2001, p. 161.

${ }^{20}$ Sfântul Ioan Gură de Aur, Comentariile sau Explicarea Epistolei I către Tesalonicieni. Omilia II, în volumul Comentariile sau Explicarea Epistolei către Coloseni, Corinteni, I şi II Tesaloniceni a Sfântului Apostol Pavel, traducere din limba elină, ediţia Oxonia, 1855, de Arhim. Theodosie Athanasiu, Bucureşti, 1905, p. 179, în volumul Lumina Sfintelor Scripturi (Antologie tematică din opera Sfântului Ioan Gură de Aur), antologie şi studii introductive Drd. Liviu Petcu, vol. II (Î-Z), Bucureşti, TRINITAS, 2007, p. 682. 
în exprimarea aceluiaşi mare Sfânt Părinte, soţia sau femeia trebuie să fie soţului ei „,eea mai puternică doctorie de veselie” ${ }^{21}$, „tovarăşul vieţii şi al corabiei acesteia”吃, „port” şi „liman” bărbatului ei.

\section{Concluzii}

Omului trebuie să îi fie trezită şi activată conştiinţa, el trebuie să realizeze că este un imago Dei, iar această idee nu constituie o aprofundare, o noutate sau o reuşită teologică, ci este un dat şi o constantă în istoria umanităţii în general ${ }^{23}$. Realitatea după care se conduce lumea devine, din ce în ce mai mult, ancorată într-o altă modă decât „,moda lui Dumnezeu”.

Virtuţile ajută la purificarea persoanei şi a simţurilor, mintea conlucrează cu inima, logicul cu sentimentalul, iar omul se îndumnezeieşte prin conlucrarea sa cu harul divin. Prin exercitarea tuturor virtuţilor ele se completează unele pe altele formând un tot unitar. Prin voia sa liberă, cu care a fost înzestrat de la creaţie, omul se află şi este liber să aleagă între a deveni „rob patimilor” şi a nu se pleca lor; are puterea de a alege între păcat şi virtute, aceasta din urmă fiind singura în stare să-i dăruiască omului ,cununa nemuririi””24.

${ }^{21}$ Sfântul Ioan Gură de Aur, Omilia XXVI, în volumul Comentariile sau Tâlcuirea Epistolei întâi către Corinteni a celui întru sfinţi părintelui nostru Ioan Hrisostom, Arhiepiscopul Constantinopolului, ediţie revizuită de Constantin Făgeţean, Bucureşti, Editura Sophia-Editura Cartea Ortodoxă, 2005, p. 279.

${ }^{22}$ Idem, Omilia XXVI, în vol. cit., p. 280.

${ }^{23}$ Pr. George Remete, Fiinţa şi credinţa, Vol. 2, Persoana, Bucureşti, Editura Paideia, 2015, p. 762.

${ }^{24}$ Sfântul Antonie cel Mare, Invăţături despre viaţa monahală, în Filocalia sfintelor nevoinţe ale desăvârşirii, volumul 1, traducere, introducere şi note de Pr. prof. dr. Dumitru Stăniloae, Ediţia a IV-a, Bucureşti, Editura Harisma, 1993, p. 32: „Dacă vrei, eşti rob patimilor; şi iarăşi, dacă vrei, eşti liber să nu te pleci patimilor fiindcă Dumnezeu te-a făcut cu voie liberă. Iar cel ce biruie patimile trupului se încununează cu nemurirea. Căci de n-ar fi patimile, n-ar fi nici virtuţile, nici cununile dăruite de Dumnezeu celor vrednici dintre oameni”. 
Izvorul suprem al virtuţilor este Dumnezeu, iar familia, în calitate de chip şi asemănare a lui Dumnezeu prin unirea celor doi soţi într-un singur trup, nu poate să fie altceva decât izvor şi mărturie, la rândul ei, de virtuţi creştine. În mod logic, între bărbat şi femeie nu există egalitate, cred că nici Dumnezeu nu a intenţionat să fie aşa. Cei doi sunt nesfârşiţi de inegali şi diferiţi, întrucât fiecare are marea sa chemare şi menire, funcţ̧ile sale. El şi ea sunt poli diferiţi. Plusul nu poate fi egal cu minusul, dar tocmai din această cauză are loc atracţia dintre ei. Este imperios ca legătura celor doi să fie ancorată în Dumnezeu, iar ei să fie un veşnic izvor de virtuţi creştine, pe care să le mărturisească ,,până la marginile pământului”, doar aşa familia va fi temelie a virtuţilor şi a legăturii indisolubile dintre soţi.

\section{Bibliografie:}

Cărţi:

1. Albrecht, Gloria H., Ideals and Injuries: The Denial of Difference in the Construction of Christian Family Ideals, in Journal of the Society of Christian Ethics, 25, 1 (2005), Washington (USA), Georgetown University Press, p. 170;

2. Ava Dorotei, Ale celui intre sfinţi, părintele nostru Dorotei. Felurite invăţături lăsate ucenicilor săi când a părăsit mănăstirea Avei Serid şi a întemeiat cu ajutorul lui Dumnezeu mănăstirea sa, după moartea Avei Ioan, proorocul, şi după tăcerea desăvârşită a Avei Varsanufie, în Filocalia sfintelor nevoinţe ale desăvârşirii, volumul IX, Traducere, introducere şi note de Pr. Prof. Dr. Dumitru Stăniloae, Bucureşti, Editura Institutului Biblic şi de Misiune al Bisericii Ortodoxe, 1981;

3. Cahill, Lisa Sowle, A Christian Social Perspective on the Family, in The Mennoite Quarterely Reviews, 75, Nr. 2, April, the Goshen College (USA), 2001;

4. Evdokimov, Paul, Ortodoxia, Traducere de Dr. Irineu Ioan Popa, Bucureşti, EIBMBOR, 1996;

5. Julius, Isaac Jesuvi, Globalization and Christian ministry to the family, in Ogbomoso Journal of Theology, 10 Dec. 2005, Nigeria;

6. Kaleda, Gleb, Biserica din casă, trad. din limba rusă de Lucia 


\section{Alin-Vasile GOGA}

Ciornea, Bucureşti, Editura Sophia, 2008;

7. Nil Ascetul, Cuvânt ascetic, în Filocalia sfintelor nevoinţe ale desăvârşirii, volumul I, Traducere, introducere şi note de Pr. Prof. Dr. Dumitru Stăniloae, Bucureşti, Editura Institutului Biblic şi de Misiune al Bisericii Ortodoxe, 1981;

8. Pop-Bistriţeanul, PS Irineu, Chipul lui Hristos în viaţa morală a creştinului, Cluj-Napoca, Editura Renaşterea, 2001;

9. Remete, George, Fiinţa şi credinţa, Vol. 2, Persoana, Bucureşti, Editura Paideia, 2015;

10. Sfântul Antonie cel Mare, Invăţături despre viaţa monahală, în Filocalia sfintelor nevoinţe ale desăvârşirii, volumul 1, traducere, introducere şi note de Pr. prof. dr. Dumitru Stăniloae, Ediţia a IV-a, Bucureşti, Editura Harisma, 1993;

11. Sfântul Ioan Gură de Aur, Omilia XXVI, în volumul Comentariile sau Tâlcuirea Epistolei întâi către Corinteni a celui întru sfinţi părintelui nostru Ioan Hrisostom, Arhiepiscopul Constantinopolului, ediţie revizuită de Constantin Făgeţean, Bucureşti, Editura Sophia-Editura Cartea Ortodoxă, 2005;

12. Sfântul Isaac Sirul, Cuvinte despre sfintele nevoinţe, în Filocalia sfintelor nevoinţe ale desăvârşirii, volumul $\mathrm{X}$, Traducere, introducere şi note de Pr. Prof. Dr. Dumitru Stăniloae, Bucureşti, Editura Institutului Biblic şi de Misiune al Bisericii Ortodoxe, 1981;

13. Talasie Libianul, Despre dragoste, înfrânare şi petrecerea cea după minte, în Filocalia sfintelor nevoinţe ale desăvârşirii, volumul IV, Traducere, introducere şi note de Pr. Prof. Dr. Dumitru Stăniloae, Bucureşti, Editura Institutului Biblic şi de Misiune al Bisericii Ortodoxe, 1981;

\section{Articole:}

1. Răducă, Vasile, Familia creştină şi riscul secularizării, în „Lumina de duminică", 6 februarie 2011.

\section{Surse web:}

1. http://ziarullumina.ro/darurile-duhului-sfant-82548.html. 